\title{
Effect of gypsum and lime on wheat growth in pots containing an acidic subsoil
}

\author{
C. D. A. McLAY and G. S. P. RITCHIE \\ Department of Soil Science and Plant Nutrition, University of Western Australia, Nedlands, Western
Australia 6009 .
}

\begin{abstract}
A pot experiment was conducted to establish whether gypsum or lime could increase wheat growth in an acid subsoil. Wheat (Triticum aestivum c.v. Gutha) was grown in $3 \mathrm{~kg}$ of soil which had been mixed with basal nutrients and different rates of gypsum and lime. Wheat in the treatment which received no gypsum or lime showed the most severe nutrient deficiency symptoms and had the lowest shoot and root dry weights. Lime treatments increased shoot and root growth 2 to 3 fold and decreased the concentration of total $\mathrm{Al}$ and the calculated activities of all Al species. Gypsum increased shoot dry weight to up to $50 \%$ but decreased root dry weight and root length compared with unamended soil; it had little effect on the $\mathrm{pH}$ and concentration of total $\mathrm{Al}$ in the soil solution but decreased the sum of the activity of monomeric $\mathrm{Al}$ ions and increased the activity of the $\mathrm{AlSO}_{4}^{+}$ion pair. Both gypsum and lime increased uptake of $\mathrm{Ca}, \mathrm{Mg}, \mathrm{S}, \mathrm{P}$ and $\mathrm{K}$ in plant shoots. It is suggested that lime increased plant growth by increasing the $\mathrm{pH}$ and markedly decreasing the concentration of $\mathrm{Al}$ in the soil solution, enabling plants to take up other nutrients from the soil. It is further suggested that gypsum decreased the activity of toxic monomeric Al species and therefore enabled better nutrient uptake. The results indicate that subsurface incorporation of lime would be the best method for improving wheat growth on yellow sandplain soils in Western Australia if an economic method for incorporation of lime into the subsoil could be developed.
\end{abstract}

\section{Introduction}

Aluminium toxicity in an acidic subsoil $(>15 \mathrm{~cm}$ depth) has been shown to be the main cause of low wheat yields in a large area (about $10^{6}$ ha) of deep yellow sandplain soils in the eastern wheatbelt of Western Australia (Carr et al., 1991). Field experiments recently conducted on these soils have shown that wheat yields can be increased up to 55\% using gypsum applied to the surface at a rate of $3 \mathrm{tha}^{-1}$ or higher (McLay et al., 1993a). Surface-applied lime in contrast, increased wheat yields by up to only $15 \%$, whilst the application of gypsum and lime together generally led to the largest increases in yield ( $77 \%$ higher than control plots). Measurement of changes to soil chemical properties showed that leaching of amendments intothe subsoil was very important for treatments to be effective (McLay et al., 1993b). Whereas gyspum leached rapidly into the subsoil, lime movement was confined predominantly to the topsoil in the first two years following application to the surface. To establish the potential increases in wheat yield by incorporating gypsum or lime directly into the subsoil, we conducted a pot experiment to investigate wheat responses to different rates of gypsum and lime which was fully mixed with the acidic subsoil.

\section{Materials and methods}

The acidic subsoil of a yellow sandplain soil was 
collected from $15-40 \mathrm{~cm}$ depth at Carrabin in the eastern wheatbelt of Western Australia $\left(32^{\circ} \mathrm{S}\right.$., $117^{\circ}$ E.). Details of the yellow sandplain soils have been given by Carr et al. (1991). Soil was air-dried and sieved less than $2 \mathrm{~mm}$. Soil $(3 \mathrm{~kg})$ was weighed into polythene bags and the following basal nutrients added $\left(\mathrm{mg} \mathrm{pot}^{-1}\right)$ in a $100 \mathrm{~mL}$ solution: $\mathrm{KH}_{2} \mathrm{PO}_{4}(1200) ; \mathrm{MgCl}_{2} \cdot 6 \mathrm{H}_{2} \mathrm{O}$ (200); $\mathrm{H}_{3} \mathrm{BO}_{3}(2) ; \mathrm{CuCl}_{2} .2 \mathrm{H}_{2} \mathrm{O}(10) ; \mathrm{ZnSO}_{4} \cdot 2 \mathrm{H}_{2} \mathrm{O}$ (15); $\mathrm{MnSO}_{4} \cdot 2 \mathrm{H}_{2} \mathrm{O}(10) ; \mathrm{Na}_{2} \mathrm{MoO}_{4} \cdot 2 \mathrm{H}_{2} \mathrm{O}$ (1); $\mathrm{NH}_{4} \mathrm{NO}_{3}(160), \mathrm{Na}_{2} \mathrm{SO}_{4}(30) . \quad \mathrm{CaCl}_{2} \cdot 2 \mathrm{H}_{2} \mathrm{O}$ (200) was also added to the control treatment to prevent $\mathrm{Ca}$ deficiency limiting growth in that treatment. The soil was air-dried overnight, and five gypsum $\left(\mathrm{CaSO}_{4} .2 \mathrm{H}_{2} \mathrm{O}\right)$ and lime $\left(\mathrm{CaCO}_{3}\right)$ treatments were added in solid form as follows: control - no gypsum or lime added; G1 - $0.43 \mathrm{~g}$ gypsum $\operatorname{pot}^{-1}$ (equivalent to $0.25 \mathrm{t} \mathrm{ha}^{-1}$ ); G2 $1.70 \mathrm{~g}_{\text {gypsum }}$ pot $^{-1}$ (equivalent to $1.0 \mathrm{t} \mathrm{ha}^{-1}$ ); $\mathrm{L} 1$ - $3.40 \mathrm{~g}$ lime pot $^{-1}$ (equivalent to $2.0 \mathrm{t}$ ha-1); $\mathrm{G} 2+\mathrm{L} 1-1.70 \mathrm{~g}$ gypsum pot $^{-1}+3.40 \mathrm{~g} \mathrm{lime}^{-1}$ Soils were thoroughly mixed, watered to $80 \%$ of field capacity moisture content, and placed in non-draining, lined $3 \mathrm{~kg}$ plastic pots in a root cooling tank $\left(18^{\circ} \mathrm{C}\right)$ in a completely randomised design. Fifteen evenly sized seeds of wheat (Triticum aestivum c.v. Gutha) were placed in each pot at a depth of $10 \mathrm{~mm}$. The pots were weighed daily and water added to maintain the moisture content. Ten days after sowing, the seedlings were thinned to 10 per pot. Every ten days pots received an additional $100 \mathrm{mg}^{-1}$ $\mathrm{NH}_{4} \mathrm{NO}_{3}$ to prevent nitrogen deficiency.

The plants in all treatments were harvested after 32 days when it became apparent that the plants grown in pots of the control treatment were suffering Al toxicity symptoms to an extent that they would not survive much longer. Shoot dry weight (SDW) and root dry weight (RDW) were recorded after oven-drying at $70^{\circ} \mathrm{C}$. Root length ( $R L$ ) was measured using a Comair root length scanner (Aerospace Industries Ltd.). Soil solution was removed by centrifugation (Gillman and Bell, 1978) and analysed for $\mathrm{pH}$, electrical conductivity $(\mathrm{EC})$, total $\mathrm{Al}\left(\mathrm{Al}_{\mathrm{T}}\right)$ using a colorimetric method (Dougan and Wilson, 1974), cations $\left(\mathrm{Na}^{+}, \mathrm{K}^{+}, \mathrm{Mg}^{2+}, \mathrm{Ca}^{2+}\right)$ by atomic absorption spectrophotometry and anions $\left(\mathrm{SO}_{4}^{2-}\right.$ $\mathrm{NO}_{3}^{-}$and $\mathrm{Cl}^{-}$) by ion-exchange chromatography. The activities of various aluminium species in the soil solution were estimated using the chemical speciation program TITRATOR (Cabaniss, 1987). The activity of total monomeric aluminium ( $\left.\sum \mathrm{Al}_{\text {mono }}\right)$ was calculated as the sum of the activities of $\mathrm{Al}^{3+}, \mathrm{Al}(\mathrm{OH})_{2}^{+}$and $\mathrm{Al}(\mathrm{OH})^{2+}$ in the solution.

Plant shoot material from selected treatments was digested in concentrated nitric acid and analysed for macro and trace elements by inductively coupled plasma atomic emission spectrometry (ICPAES).

\section{Results}

Plant growth

The largest increases in SDW (about $300 \%$ higher than control SDW) were recorded in the limed soil (Table 1). Shoot dry weight was also higher in gypsum amended soil than unamended soil (by up to $50 \%$ at the highest rate of application) and increased as the rate of gypsum added increased. The addition of gypsum plus lime together resulted in slightly lower SDW than the addition of lime alone.

Lime also caused the largest increases in RDW and RL which were approximately 2.3 times (RDW) and 4.0 times (RL) times higher than the control (Table 1). However, RDW and RL were slightly lower in gypsum-treated soil than the unamended soil. The addition of lime plus gypsum resulted in a slightly smaller increase in SDW than the application of lime alone.

The shoot to root ratio increased as the rate of gypsum application increased (Table 1). The

Table 1. Effect of gypsum and lime amendments on shoot dry weight (SDW), root dry weight (RDW) and root length (RL).

\begin{tabular}{llll}
\hline Treatment & $\begin{array}{l}\text { SDW } \\
\left(\mathrm{g} \mathrm{pot}^{-1}\right)\end{array}$ & $\begin{array}{l}\text { RDW } \\
\left(\mathrm{g} \mathrm{pot}^{-1}\right)\end{array}$ & $\begin{array}{l}\mathrm{RL} \\
(\mathrm{m})\end{array}$ \\
\hline Control & 0.66 & 0.37 & 23.73 \\
Gypsum (G1) $^{a}$ & 0.77 & 0.34 & 28.40 \\
Gypsum (G2) $^{b}$ & 0.96 & 0.22 & 17.50 \\
Lime (L1) $^{c}$ & 2.03 & 0.85 & 94.63 \\
G2+L1 $_{\text {LSD }}$ & 1.77 & 0.69 & 72.27 \\
\hline
\end{tabular}

${ }^{a} 0.43 \mathrm{~g} \mathrm{pot}^{-1} ;^{b} 1.70 \mathrm{~g} \mathrm{pot}^{-1} ;^{c} 3.40 \mathrm{~g} \mathrm{pot}^{-1}$ 
Table 2. Selected chemical properties of the soil solution at completion of pot experiment. Total $\mathrm{Al}, \mathrm{Ca}^{2+}, \mathrm{Mg}^{2+}$ and $\mathrm{SO}_{4}^{2-}$ are concentrations. Total monomeric $\mathrm{Al}(\Sigma \mathrm{Al}$ mono $)$ and $\mathrm{A}_{1 \mathrm{SO}_{4}^{+}}^{+}$activities were calculated from mean concentrations of other ions in solution.

\begin{tabular}{llllllrrr}
\hline Treatment & $\mathrm{pH}$ & $\begin{array}{l}\text { Ionic } \\
\text { strength }\end{array}$ & $\begin{array}{l}\text { Total A1 } \\
(\mu M)\end{array}$ & $\begin{array}{l}\mathrm{Ca}^{2+} \\
(\mu M)\end{array}$ & $\begin{array}{l}\mathrm{Mg}^{2+} \\
(\mu M)\end{array}$ & $\begin{array}{r}\mathrm{SO}_{4}^{2-} \\
(\mu M)\end{array}$ & $\begin{array}{r}\sum_{\mathrm{Al}_{\text {mono }}} \\
(\mu M)\end{array}$ & \multicolumn{1}{c}{$\mathrm{AlSO}_{4}^{+}$} \\
\hline Control & 3.50 & 0.031 & 28.8 & 2281 & 5164 & 899 & 5.1 & 6.9 \\
Gypsum (G1)a & 3.55 & 0.039 & 28.3 & 5295 & 6073 & 1953 & 1.7 & 17.3 \\
Gypsum (G2)b & 3.64 & 0.047 & 28.6 & 12355 & 5618 & 9650 & 0.4 & 21.7 \\
Lime (L1)c & 5.54 & 0.044 & 7.7 & 20651 & 1881 & 11750 & 0.3 & 0.1 \\
G2+L1 & 5.35 & 0.037 & 1.6 & 22419 & 1819 & 12423 & 0.8 & 0.1 \\
LSD $_{(0.05)}$ & 0.39 & 0.006 & 8.0 & 2518 & 3052 & 627 & N.A. & N.A. \\
\hline
\end{tabular}

${ }^{\mathrm{a}} 0.43 \mathrm{~g} \mathrm{pot}^{-1} ; \mathrm{b} 1.70 \mathrm{~g} \mathrm{pot}^{-1} ; 3.40 \mathrm{~g} \mathrm{pot}^{-1}$

N.A. not applicable

shoot to root ratio was slightly higher in the presence of lime plus gypsum than the presence of lime alone.

\section{Soil solution chemical properties}

Gypsum application resulted in large increases in soil solution ionic strength, concentration of $\mathrm{Ca}$ and $\mathrm{SO}_{4}$-ions, and a small increase in $\mathrm{pH}$ (Table 2). Monomeric Al decreased as the rate of gypsum increased. Liming the subsoil resulted in markedly higher soil solution $\mathrm{pH}$, ionic strength, and concentrations of $\mathrm{Ca}$ - and $\mathrm{SO}_{4}$-ions, and lower concentrations of total $\mathrm{Al}$ and other $\mathrm{Al}$ species. The application of gypsum plus lime generally led to changes in chemical properties of the soil solution similar to the application of lime alone, except that the concentrations of $\mathrm{Ca}$ and $\mathrm{SO}_{4}$-ions were higher.

\section{Plant nutrient content}

Macro-nutrient content of the wheat shoot material generally followed the order gypsum plus lime $>$ lime $>$ gypsum $>>$ control (Table 3 ).
There was little difference recorded in the trace element content of plant material between any of the treatments (data not presented).

\section{Discussion}

The addition of lime to the subsoil resulted in the largest increase in wheat growth due to an increase in $\mathrm{pH}$ and subsequent decrease in concentration of $\mathrm{Al}$ in the soil solution. Gypsum also increased SDW due to a decrease in the concentration of toxic forms of $\mathrm{Al}$ in the soil solution. It is suggested that subsoil incorporation of lime would be the most effective method for ameliorating subsoil acidity in this soil type in the field.

Lime markedly increased wheat shoot and root growth by up to $300 \%$ compared with the unamended control soil. Previous research on yellow sandplain soils in the field, in contrast, had shown a general lack of responses to lime due to limited movement from the surface into the subsurface (McLay et al., 1993a,b). The results reported here indicate that direct

Table 3. Concentrations of plant macro-nutrients $(\%)$ in wheat shoot material from treatments at completion of experiment. (Values given are means of replicates \pm standard errors).

\begin{tabular}{|c|c|c|c|c|c|}
\hline Treatment & $\mathrm{Ca}$ & $\mathrm{Mg}$ & $\mathrm{S}$ & $\mathbf{P}$ & $\mathrm{K}$ \\
\hline control & $0.11 \pm 0.00$ & $0.09 \pm 0.01$ & $0.23 \pm 0.00$ & $0.11 \pm 0.01$ & $5.39 \pm 0.45$ \\
\hline Gypsum (Gs) & $0.33 \pm 0.02$ & $0.16 \pm 0.01$ & $0.38 \pm 0.01$ & $0.24 \pm 0.00$ & $6.69 \pm 1.24$ \\
\hline Lime (L2) & $0.66 \pm 0.02$ & $0.18 \pm 0.01$ & $0.36 \pm 0.01$ & $0.24 \pm 0.00$ & $8.04 \pm 0.01$ \\
\hline $\mathrm{G} 2+\mathrm{L} 2$ & $0.72 \pm 0.02$ & $0.19 \pm 0.01$ & $0.39 \pm 0.01$ & $0.28 \pm 0.02$ & $7.79 \pm 0.19$ \\
\hline
\end{tabular}

a $1.70 \mathrm{~g} \mathrm{pot}^{-1} ;{ }^{\mathrm{b}} 3.40 \mathrm{~g} \mathrm{pot}^{-1}$ 
incorporation of lime into the subsoil would be the most effective method to increase wheat yields. However, the cost of subsoil incorporation of lime may be a limiting factor in the low input farming systems of the eastern wheatbelt of Western Australia.

Gypsum also increased SDW although considerably less than lime. The $50 \%$ increase in SDW with $1 \mathrm{t} \mathrm{ha}^{-1}$ gypsum mixed into the subsoil is similar to grain yield increases reported with surface applications of gypsum in the field (McLay et al., 1993a). The decrease in the shoot to root ratio that was observed as the rate of gypsum application increased indicates that the wheat allocated more of its increased productivity to shoot growth than root growth. This is different to previous reports which have shown that gypsum application to ameliorate subsurface acidity may either increase (e.g. Sumner and Carter, 1988; Alva and Sumner, 1990) or cause no change (e.g. Wright et al., 1985) to root growth in Al toxic soils, and indicates that root bioassays alone may be unsuitable for predicting wheat responses to gypsum in acidic subsoils. Addition of gypsum with the lime did not further improve wheat growth compared with the addition of lime alone which is in contrast to the highest yields which have been recorded in the field when lime and gypsum have been added together (McLay et al., 1993a).

Wheat grown in the control treatment appeared extremely nutrient deficient, a common symptom of Al toxicity, and nutrient analysis confirmed that the wheat was incapable of adequate nutrient uptake from the soil solution. Liming the soil increased the $\mathrm{pH}$ of the soil solution and therefore decreased the toxic $\mathrm{Al}$ to negligible concentrations at the $2 \mathrm{t} \mathrm{ha}^{-1}$ lime rate, enabling better root proliferation and greater nutrient uptake. Gypsum did not change either $\mathrm{pH}$ or total $\mathrm{Al}$ in the soil solution. However, the amount of Al present in monomeric forms was considerably lower in gypsum-amended soil than the control soil, and the amount present as the non-toxic $\mathrm{AlSO}_{4}^{+}$ion pair was substantially higher in the gyspum treatments, thereby decreasing the amount of Al which was toxic to plants and enabling better nutrient uptake from the acidic soil solution. The addition of basal nutrients in the pot experiment resulted in approximately ten-fold higher ionic strength than would normally be measured in the solution of unamended subsoil in the field, and resulted in less monomeric $\mathrm{Al}$ and more $\mathrm{AlSO}_{4}^{+}$than would normally be measured in unamended yellow sandplain subsoils. It is likely therefore that the magnitude of the increase in plant growth following lime and gypsum addition is lower than would be expected if basal nutrients were not added.

\section{References}

Alva A K and Sumner M E 1990 Plant and Soil 128, 127134.

Cabaniss S E 1987 Env. Sci. and Tech. 21, 209-10.

Carr S J, Ritchie G S P and Porter W M 1991 Aust. J. Agric. Res.42, 875-892.

McLay C D A, Ritchie G S P and Porter W M 1993a Aust J. Ag. Res. (submitted)

McLay C D A, Ritchie G S P and Porter W M 1993b Aust J. Soil Res. (submitted)

Sumner M E and Carter E 1988 Commun. Soil Sci. Plant Anal. 19, 1309-1318.

Wright R J, Hern J L, Baligar V C and Bennet O L 1985 Commun. Soil Sci Plant Anal. 16, 179-192. 